\title{
Biochemical and molecular tolerance of Carpobrotus acinaciformis L. halophyte plants exposed to high level of $\mathrm{NaCl}$ stress
}

\section{$\mathrm{NaCl}$ stresine maruz bırakılan Carpobrotus acinaciformis L. halofit bitkisinin biyokimyasal ve moleküler tepkileri}

\author{
Sema KARAKAS $^{1 *}$ iD Murat DiKiLiTAS $^{2}$ iD , Rukiye TIPIRDAMAZ $^{3}$ iD \\ ${ }^{1}$ Harran University, Faculty of Agriculture, Department of Soil Science and Plant Nutrition, Şanlıurfa, Turkey \\ ${ }^{2}$ Harran University, Faculty of Agriculture, Department of Plant Protection, Şanlıurfa, Turkey \\ ${ }^{3}$ Hacettepe University, Faculty of Science, Department of Biology, Ankara, Turkey
}

\section{To cite this article:}

Karakas, S., Dikilitas, M., \& Tıpırdamaz, R. (2019). Biochemical and molecular tolerance of Carpobrotus acinaciformis L. halophyte plants exposed to high level of $\mathrm{NaCl}$ stress. Harran Tarım ve Gıda Bilimleri Dergisi, 23(1): 99-107. DOI: 10.29050 /harranziraat.464 133

Address for Correspondence: Sema KARAKAS e-mail:

skarakas@harran.edu.tr

Received Date:

26.09.2018

Accepted Date:

18.01.2019

(C) Copyright 2018 by Harran University Faculty of Agriculture. Available on-line www.dergipark.gov.tr/harranziraat

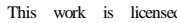
This work is licensed
under a Creative Commons Attribution
Non Commercial 4.

\section{ABSTRACT}

Carpobrotus acinaciformis L. plant is a kind of halophyte that is able to survive in high salt conditions. It is important to determine its physiological, biochemical and molecular limit of $\mathrm{NaCl}$ stress if one aims to use it for phytoremediation purpose. In this study, the alkaline protocol of the modified plant comet assay were used for rapid detection of DNA damage in C. acinaciformis L. plants exposed to a series of $\mathrm{NaCl}$ stress concentrations (0-, 50-, 100-, 200-, 300-, 400 and $500 \mathrm{mmol} \mathrm{L}^{-1}$ ) in hydroponic conditions for 2 weeks. DNA damage was measured as the values of percentage of DNA in tails and tail length. The halophyte C. acinaciformis $\mathrm{L}$. did not show any dose response up to $400 \mathrm{mmol} \mathrm{L}^{-1} \mathrm{NaCl}$ level in terms of DNA damages. DNA integrity measured via comet assay showed that DNA preserved its original shape up to $400 \mathrm{mmol} \mathrm{L}^{-1} \mathrm{NaCl}$ level. However, the very high concentrations of $\mathrm{NaCl}$ (400 and $500 \mathrm{mmol} \mathrm{L}^{-1}$ ) caused DNA damages. When physiological and biochemical parameters such as proline, chlorophyll $a$ and $b$, peroxidase (POX), catalase (CAT), $\mathrm{H}_{2} \mathrm{O}_{2}$, malondialdehyde (MDA) contents were examined, oxidant molecules such as $\mathrm{H}_{2} \mathrm{O}_{2}(0.912$ $3.72 \mathrm{\mu mol} \mathrm{g}^{-1} \mathrm{Fwt}$ ) and MDA (7.1-34 $\mathrm{nmol} \mathrm{g}^{-1} \mathrm{Fwt}$ ) gradually increased along with the increase of $\mathrm{NaCl}$ concentrations, $\mathrm{p}<0.05$. On the other hand, antioxidant enzyme POX and an osmolyte molecule proline slightly increased up to $400 \mathrm{mmol} \mathrm{L}^{-1} \mathrm{NaCl}$ level then slightly decreased after that. Similar issues were obtained from that of protease enzyme which indicates the power of protein hydrolysis in which a slight decrease (182-95 Unit $\mathrm{mg}^{-1}$ protein) over a dose of $\mathrm{NaCl}$ was evident. Chlorophyll contents and CAT activity were not affected upon increase of $\mathrm{NaCl}$ concentrations. This study showed that the halophyte $\mathrm{C}$. acinaciformis $L$. can be easily used to remove salt up to $400 \mathrm{mmol} \mathrm{L}^{-1} \mathrm{NaCl}$ concentrations from a saline-affected soil. Measuring DNA damage is concluded as a very useful parameter to find out what level of $\mathrm{NaCl}$ could be tolerated if a halophyte plant is aimed to remediate the saline soils.

Key Words: Halophyte, $\mathrm{NaCl}$ stress, Comet assay, SCGE, DNA damage

öz

Carpobrotus acinaciformis L. bitkisi yüksek tuz koşullarında yaşayabilen bir çeşit halofit bitkidir. Bu bitki fitoremediasyon çalışmaları için kullanılmak üzere planlandığında, bu bitkinin tuz stresine karşı fizyolojik, biyokimyasal ve moleküler sınırlarını belirlemek önem arz etmektedir. C. acinaciformis L. bitkisinde DNA hasar seviyesini belirlemek için hidroponik koşullarda 2 hafta süre ile tuz stresine (0-, 50-, 100-, 200-, 300-, 400 and $500 \mathrm{mmol} \mathrm{L}^{-1}$ ) maruz bırakılan bitkilerde modifiye edilmiş alkali bitki comet assay metodu kullanılmıştır. DNA hasarı kuyruk uzunluğu ve kuyrukta DNA yüzdesi olarak ölçülmüştür. Halofit C. acinaciformis $\mathrm{L} 400 \mathrm{mmol} \mathrm{L}{ }^{-1} \mathrm{NaCl}$ seviyesine kadar DNA hasarı ile ilgili olarak doz tepkisi göstermemiştir. Comet assay ile ölçülen yönteme göre halofit bitkilerin DNA bütünlüğünü $400 \mathrm{mmol} \mathrm{L}^{-1} \mathrm{NaCl}$ seviyesine kadar 
korunduğu gözlenmiştir. Fakat, çok daha yüksek $\mathrm{NaCl}$ konsantrasyonları (400 ve $500 \mathrm{mmol} \mathrm{L}^{-1}$ ) DNA hasarına yol açmıştır. Prolin, klorofil $a$ ve $b$, peroksidaz (POX), katalaz (CAT), $\mathrm{H}_{2} \mathrm{O}_{2}$, malondialdehid (MDA) içerikleri gibi fizyolojik ve biyokimyasal parametreler incelendiğinde, oksidant moleküllerden $\mathrm{H}_{2} \mathrm{O}_{2}\left(0.912-3.72 \mu \mathrm{mol} \mathrm{g}^{-1}\right.$ taze ağıllık) and MDA (7.1-34 nmol g ${ }^{-1}$ taze ağırlık) artan tuz konsantrasyonu ile paralel olarak sıralı artış göstermiştir, $p<0.05$. Diğer yandan, antioksidant enzimlerden POX ve bir osmolit olan prolin $400 \mathrm{mmol} \mathrm{L}^{-1} \mathrm{NaCl}^{\prime}$ e kadar hafifçe artış göstermiş daha sonra tekrar düşmüştür. Benzer durumlar protein hidrolizini belirlemede kullanılan proteaz enzim (182-95 Unit $\mathrm{mg}^{-1}$ protein) seviyesinde de görülmüş, artan $\mathrm{NaCl}$ dozuna bağlı olarak enzim miktarı kademeli olarak azalmıştır. Klorofil miktarı ve CAT enzim seviyesi NaCl konsantrasyon artışına bağı̆ı olarak değişim göstermemiştir. Bu çalışma, C. acinaciformis L. bitkisinin tuzdan etkilenmiş topraklarda $400 \mathrm{mmol}$ $\mathrm{L}^{-1} \mathrm{NaCl}^{\prime}$ e kadar olan tuz konsantrasyonunu uzaklaştırmada rahatlıkla kullanılabileceğini ortaya koymuştur. DNA hasarıı ölçmek, tuzlu alanları ıslah etmede kullanılacak halofit bitkinin hangi seviyede $\mathrm{NaCl}$ stresine dayanabileceğini belirlemede çok kullanışlı bir parametre olarak kaydedilmiştir.

Anahtar Kelimeler: $\mathrm{NaCl}$ stres, Comet assay, SCGE, DNA hasarı

\section{Introduction}

Salinity is a major factor limiting crop production in the world. Salinity has an effect on almost every aspect of the physiology and biochemistry of plants and significantly reduces yield (Pirasteh-Anosheh et al., 2016; Suo et al., 2017). Salinity induces ion imbalance, osmotic stress, oxidative damage, and other subsequent disturbances (Pirasteh-Anosheh et al., 2016). Plants under stressful conditions produce reactive oxygen species (ROS), however, they are able protect their cells and subcellular systems against the effects of (ROS) by enzymes such as superoxide dismutase, catalase, peroxidase, glutathione reductase, polyphenol oxidase and non-enzymatic antioxidants such as ascorbate and glutathione (Agarwal and Pandey, 2004). ROS types such as superoxide $\left(\mathrm{O}_{2}^{-}\right)$, hydrogen peroxide $\left(\mathrm{H}_{2} \mathrm{O}_{2}\right)$, hydroxyl radical $\left(\mathrm{HO}^{-}\right)$, and singlet oxygen $\left(\mathrm{O}^{-}\right)$have capacity to cause oxidative damage in proteins, DNA and lipids (Sharma et al., 2012; Tripathy and Oelmüller, 2012). Malondialdehyde (MDA) content, a product of lipid peroxidation, has been considered as an indicator of oxidative damage. Similarly, $\mathrm{H}_{2} \mathrm{O}_{2}$ has been regarded as a good marker for oxidative stress. These molecules could decrease the membrane stability and reduce the metabolic functions of cells (Miller et. al., 2010). By using above markers, we could easily differentiate the salt-tolerant and saltsensitive plants species. Recently, DNA damage studies via the use of comet assay have enabled the plant scientists more straight forward approach. Conditions of plants under stress could be evaluated via the measurement of DNA integrity. The comet assay (single-cell gel electrophoresis) is a simple method for measuring deoxyribonucleic acid (DNA) strand breaks in eukaryotic cells. It determines single and double-strand breaks in DNA.

Halophytes are salt-resistant or salt-tolerant plants and they have remarkable ability to complete their life cycle in saline conditions (Flowers and Colmer, 2008; Grigore et al., 2014). Therefore, halophytes have been explored for saline agriculture in many studies (Flowers and Colmer, 2015; Karakas et al., 2017). However, little information is available on well-defined molecular defense mechanisms against salt stress (Anjum et al., 2012; Joshi et al., 2015). Determination of defense or tolerance mechanisms of halophytes in a molecular level would enable us to decide whether the selected halophyte is suitable that have potential remediation capacity in terms of salinity and heavy metal toxicity.

Carpobrotus acinaciformis L. is a fast growing, succulent perennial plant belonging to the family of Azioaceae. It is commonly inhabited in the Mediterranean, all of which share a similar climate; it was oriented from South Africa. It is resistant to harsh conditions such as salt and drought (Suehs et al., 2003; Traveset et. al., 2008). Its growth is rapid and the coloniziation capacity is high in the ground (D'Antonio, 1993; Price and Marshall 1999).

In this study, the responses of $C$. acinaciformis L. to $\mathrm{NaCl}$ stress (0-, 50-, 100-, 200-, 300-, 400 and $500 \mathrm{mmol} \mathrm{L}^{-1}$ ) were tested to characterize its salt tolerance capacity for the possible phytoremediation approach. 


\section{Material and Methods}

The halophyte plants (C. acinaciformis L.) were collected at the clonal growth stage from the gardens of Harran University, Turkey. The plants were cut at equal length and were exposed to series of $\mathrm{NaCl}$ stress concentrations (0-, 50-, 100-, 200-, 300-, 400 and $500 \mathrm{mmol} \mathrm{L}^{-1}$ ) in hydroponic conditions for 2 weeks. Control plants were treated with $\mathrm{dH}_{2} \mathrm{O}$ only.

Measurement of physiological and biochemical parameters

A chlorophyll determination was performed according to the method of Arnon (1949). For the analysis, a $0.5 \mathrm{~g}$ leaf sample was homogenized in $5 \mathrm{~mL}$ acetone:water $(80: 20 \% \mathrm{v} / \mathrm{v})$ mixture. The homogenate was prepared via filtering the samples through Whatman No.1 filter paper and centrifuged at $10000 \mathrm{~g}$ for $5 \mathrm{~min}$ to minimize the residual pellet. The supernant was then read against the blank containing $80 \%$ acetone control alone. The measurement was made at $663 \mathrm{~nm}$ for chl $a$ and $645 \mathrm{~nm}$ for chl b in a UV spectrophotometer (UV-1700, Shimadzu).

The proline measurement was conducted according to the method of Bates et al. (1973). Acid-ninhydrin was employed as a reagent, which was obtained by dissolving (warming and agitating) $1.25 \mathrm{~g}$ of ninhydrin in $30 \mathrm{~mL}$ of glacial acetic acid and $20 \mathrm{~mL}$ of $6 \mathrm{M}$ phosphoric acid. A quantity of $0.5 \mathrm{~g}$ of leaf material was homogenized in $10 \mathrm{~mL}$ of $3 \% \mathrm{w} / \mathrm{v}$ sulfosalicylic acid, then the homogenate was filtered through Whatman No. 2 filter paper. A $2 \mathrm{~mL}$ of filtrate was mixed in a test tube with $2 \mathrm{~mL}$ of acid ninhydrin reagent and boiled at $100^{\circ} \mathrm{C}$ for one hour. The reaction was terminated in an ice bath. The reaction mixture was extracted with $5 \mathrm{~mL}$ of toluene. Tubes were thoroughly shaken for 15 20 seconds and left for further $20 \mathrm{~min}$ in order to achieve separation of the two layers. The chromophore containing toluene was removed and allowed to warm to room temperature. Absorbance of the solution was measured at 515 $\mathrm{nm}$ using a toluene blank as a reference in a spectrophotometry (UV-1700, Shimadzu). The results were expressed as $\mu \mathrm{mol} \mathrm{g}{ }^{-1}$ fresh tissue.

The malondialdehyde (MDA) content was determined according to the method of (Sairam and Saxena, 2000). A $0.5 \mathrm{~g}$ leaf tissue sample was homogenized using $10 \mathrm{~mL}$ of a $0.1 \%$ trichloroacetic acid (TCA) and the homogenate was centrifuged at $10,000 \mathrm{~g}$ for five minutes. Four $\mathrm{mL}$ of $20 \% \mathrm{v} / \mathrm{v}$ TCA containing $0.5 \% \mathrm{v} / \mathrm{v}$ thiobarbituric acid (TBA) was added to $1 \mathrm{~mL}$ of the supernatant. The solution was heated at $95^{\circ} \mathrm{C}$ for $30 \mathrm{~min}$ and then quickly cooled on ice. The mixture was centrifuged once again at $10,000 \mathrm{~g}$ for $5 \mathrm{~min}$ and the absorbance of the clean supernatant was determined at 532 and $600 \mathrm{~nm}$. The MDA content of leaves is expressed as $\mathrm{nmol}$ $\mathrm{g}^{-1}$ fresh tissue.

Catalase enzyme activity (CAT, E,C. 1.11.1.6) was determined by monitoring the decomposition of $\mathrm{H}_{2} \mathrm{O}_{2}$ according to the method of Milosevic and Slusarenko (1996). For the analysis, $0.5 \mathrm{~g}$ of plant material was homogenized in $10 \mathrm{~mL}$ of a $50 \mathrm{mM}$ Na-phosphate buffer solution, then $50 \mu \mathrm{L}$ of plant extract was added to a $2.95 \mathrm{~mL}\left(10 \mathrm{mM} \mathrm{H}_{2} \mathrm{O}_{2}, 50\right.$ $\mathrm{mM}$ Na-phosphate buffer and $4 \mathrm{mM} \mathrm{Na}{ }_{2}$ EDTA) reaction mixture and measured for 30 seconds at $240 \mathrm{~nm}$ with a UV spectrometer (UV-1700, Shimadzu). One CAT activity unit (U) is defined as a change of 0.1 absorbance unit per minute. Activity is expressed as enzyme units per gram fresh weight.

Peroxidase enzyme activity (POX, E.C.1.11.1.7) was determined by monitoring the increase in absorbance due to the tetraguaiocol formation at $470 \mathrm{~nm}$ according to the method of Cvikrova et al. (1994). For the analysis, $100 \mu \mathrm{L}$ of extract (obtained as above) was added to $3 \mathrm{~mL}$ of the reaction mixture (13 $\mathrm{mM}$ guaiacol, $5 \mathrm{mM} \mathrm{H}_{2} \mathrm{O}_{2}$, and $50 \mathrm{mM}$ Na-phosphate, $\mathrm{pH}$ 6.5). The reaction was initiated with a $\mathrm{H}_{2} \mathrm{O}_{2}$ addition and was measured at $470 \mathrm{~nm}$, using a UV spectrophotometer (UV-1700, Shimadzu) at oneminute interval until $3^{\text {rd }}$ minute. One unit of POX activity is defined as a change of 0.1 absorbance unit per minute at $470 \mathrm{~nm}$. Activity is expressed as enzyme units per gram of fresh weight. 
Protease activity was determined according to the method of Girard and Michaud (2002). One g plant was placed into $2 \mathrm{~mL}$ Eppendorf tube and then $500 \mu \mathrm{L}$ of $1 \%(\mathrm{w} / \mathrm{v})$ azocasein in $50 \mathrm{mmol} \mathrm{L}^{-1}$ Tris- $\mathrm{HCl}, \mathrm{pH}$ 8.8. Azocasein hydrolysis was initiated by incubating the tubes $2 \mathrm{~h}$ at room temperature. Proteolysis was stopped by adding $300 \mu \mathrm{l}$ of $10 \%(\mathrm{w} / \mathrm{v})$ cold trichloroacetic acid (TCA). After centrifugation for $10 \mathrm{~min}$ at $15,000 \mathrm{~g}$, $350 \mu \mathrm{l}$ of the supernatant was collected and mixed with $300 \mu \mathrm{l}$ of $1 \mathrm{~N} \mathrm{NaOH}$. Protease activity was then determined by reading the optical density of the resulting solution at $440 \mathrm{~nm}$ using a UV spectrophotometer. A change of 0.01 units per minute in absorbance was considered to be equal to one unit protease activity, which was expressed as $U$ (unit) $\mathrm{mg}^{-1}$ protein.

Hydrogen peroxide $\left(\mathrm{H}_{2} \mathrm{O}_{2}\right)$ content was determined according to the method of Velikova et al. (2000). A tissue sample of (0.1 g) was homogenized in an ice bath with $5 \mathrm{~mL}$ of $0.1 \%$ $(\mathrm{w} / \mathrm{v})$ trichloroacetic acid (TCA). The homogenate was centrifuged at $12,000 \mathrm{~g}$ for $15 \mathrm{~min}$ and $0.5 \mathrm{~mL}$ of $10 \mathrm{mM}$ potassium phosphate buffer $(\mathrm{pH}$ 7.0) and $1 \mathrm{~mL}$ of $1 \mathrm{M} \mathrm{KI}$ were added. The absorbance was read at $390 \mathrm{~nm}$ and the $\mathrm{H}_{2} \mathrm{O}_{2}$ level was calculated as $\mu \mathrm{mol} \mathrm{g}{ }^{-1} \mathrm{FW}$.

Assessment of DNA damage caused by $\mathrm{NaCl}$ was made via the comet assay method for plants (Gichner et al. 2008; Kassaye et al., 2013). Nuclei were isolated from leaves of $C$. acinaciformis $\mathrm{L}$. cuttings which were exposed to $\mathrm{NaCl}$ in hydroponic conditions. A 50-100 mg fresh weight of leaf material was mixed with $200 \mu$ l cold phosphate buffered saline (PBS) containing 50 $\mathrm{mM} \mathrm{Na}{ }_{2}$ EDTA on a $60-\mathrm{mm}$ Petri dish placed on ice. Leaf tissues were quickly chopped rather than slicing with a sharp scalpel under dim light in a dark room to collect nuclei (Pourrut et al., 2015). DNA damage was examined after the assay protocol in both control and exposed groups. Ethyl methanesulfonate (EMS) was used as a positive control.

The assay was briefly outlined as following:; Cells embedded in agarose on a microscope slide are lysed with detergent and high salt to form nucleoids containing supercoiled loops of DNA linked to the nuclear matrix. Electrophoresis performed at high $\mathrm{pH}(\mathrm{pH} \geq 13)$ results in structures resembling comets when observed under fluorescence microscopy. The intensity of the comet tail relative to the head reflects the number of DNA breaks (Collins, 2004).

\section{Result and Discussion}

\section{Assessment of Physiological parameters}

The fresh weight (FW) and dry weight (DW) of the halophyte $C$. acinaciformis increased at 50 and $100 \mathrm{mmol} \mathrm{L}^{-1} \mathrm{NaCl}$, then returned to the control values at 200 and $300 \mathrm{mmol} \mathrm{L}^{-1} \mathrm{NaCl}$, and then decreased at about 400 and $500 \mathrm{mmol} \mathrm{L}^{-1}$ $\mathrm{NaCl}$. The growth of $C$. acinaciformis was promoted at low levels of $\mathrm{NaCl}$. However, these levels have been regarded as toxic and inhibit the growth of many salt-tolerant glycophytes and many salt-tolerant crop plants (Lei et al., 2018). The halophyte $C$. acinaciformis was able to grow in the presence of $500 \mathrm{mmol} \mathrm{L}^{-1} \mathrm{NaCl}$ and remained alive at $500 \mathrm{mmol} \mathrm{L}^{-1} \mathrm{NaCl}$ which is a higher dose than salt concentration of sea water. Low levels of $\mathrm{NaCl}$ improved the growth and development of $C$. acinaciformis (Figure 1 ).

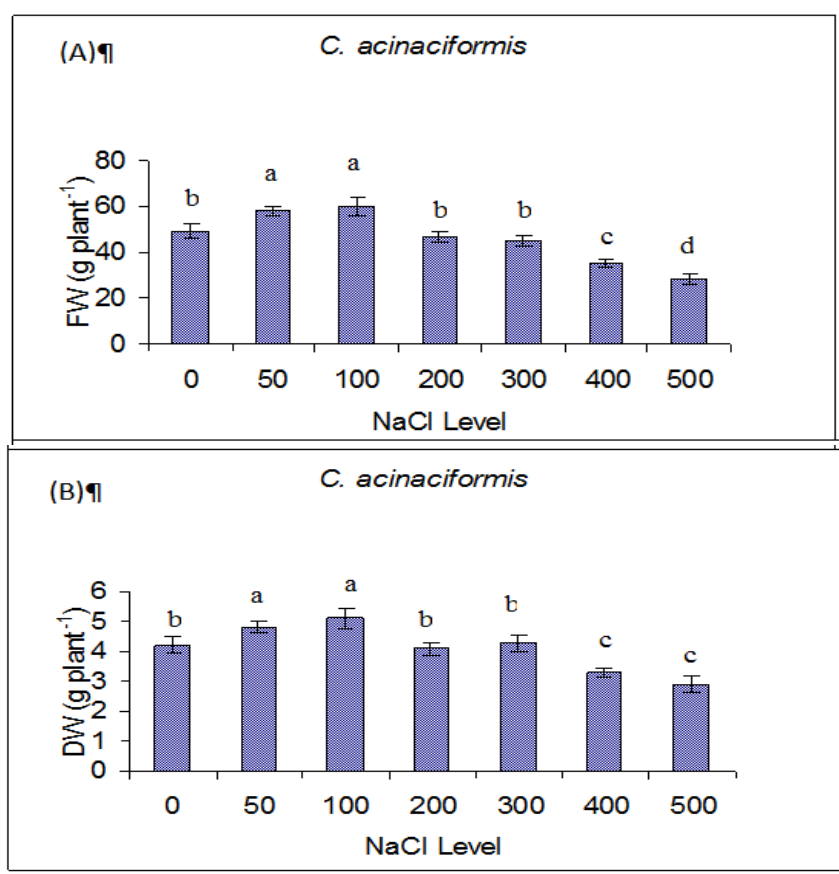

Figure 1. (A) FW and (B) DW of C. acinaciformis under $\mathrm{NaCl}$ stress. Different letters indicate significant differences $(P<0.05)$.

Şekil 1. Tuz stresi altında C. acinaciformis bitkisinin (A) Taze ağırlık, TA ve (B) Kuru ağırlık, KA değerleri. Farklı harfler istatistik olarak önemli farklılıkları ifade etmektedir $(P<0.05)$. 


\section{Assessment of biochemical parameters}

Chlorophyll $a$ and chlorophyll $b$ contents were not affected under $\mathrm{NaCl}$ stress at all $\mathrm{NaCl}$ concentrations, Figure 2. In some studies, photosynthesis was shown not to be affected by salinity and even stimulated at low salt concentrations (Kurban et al., 1999, Parida et al., 2004). However, high salinity tolerance, in general, do not affect the chlorophyll synthesis in halophytes even at high concentrations (Flowers and Colmer, 2008).

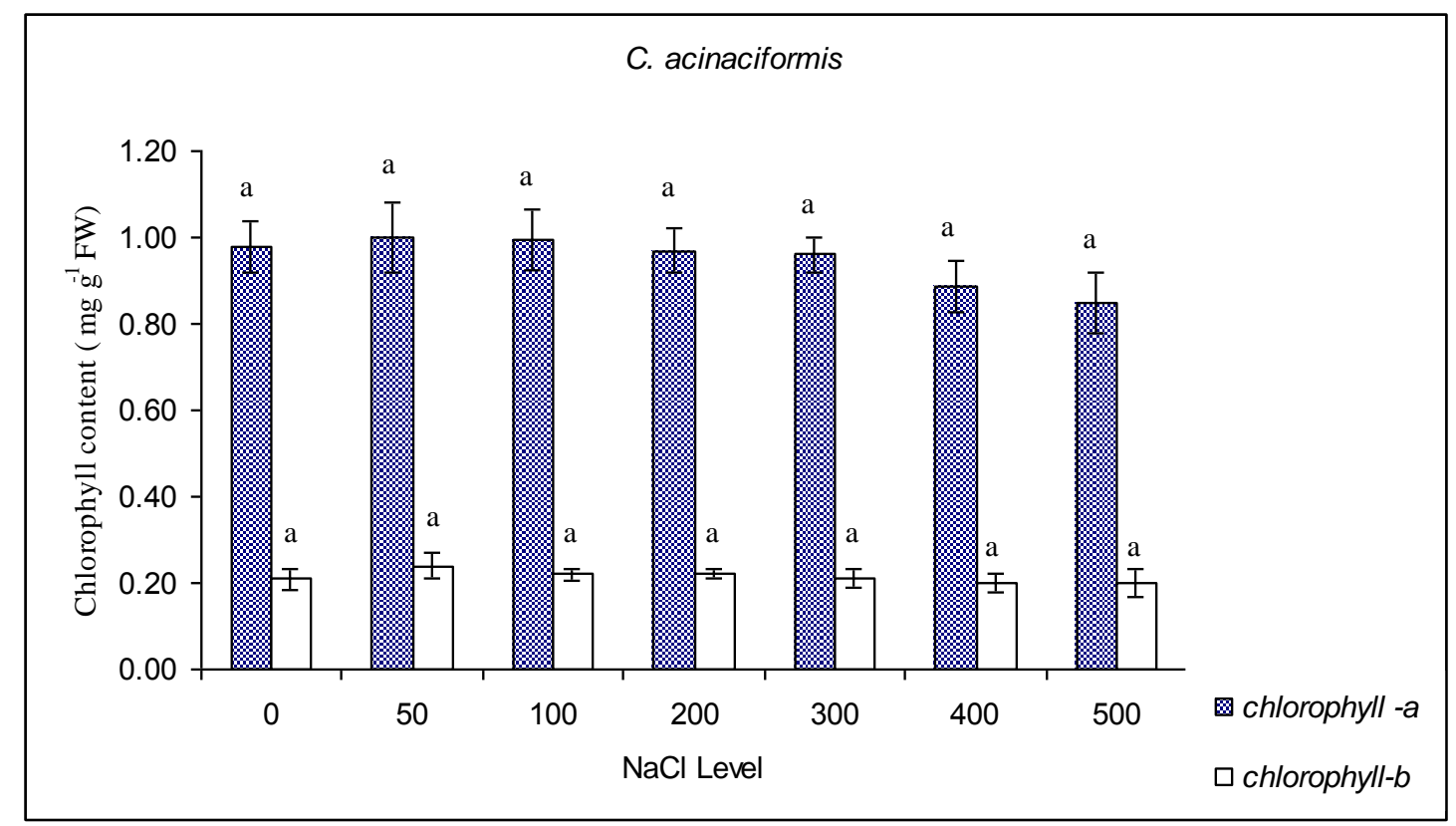

Figure 2. Content of chlorophyll $a$ and $b$.

Şekil 2. Klorofil $a$ ve $b$ içeriği.

An osmolyte molecule proline slightly increased up to $300 \mathrm{mmol} \mathrm{L}^{-1} \mathrm{NaCl}$ level, then slightly decreased. Plants sensitivity and leaf proline concentration showed that high proline contents were related to their reactivity to salt (Chérifi et al., 2016). Several plants accumulate higher level of proline in contrast to other amino acids when exposed to high salt content in the soil (Heidari et al., 2011). Proline acts as a mediator of osmotic adjustment stabilizing the effect of salt accumulation in the vacuole (Heidari et al., 2011) to protect cell membranes, several different enzymes and metabolic machinery (Zadehbagheri et al., 2014).

Oxidant molecules such as $\mathrm{H}_{2} \mathrm{O}_{2}$ (0.91-3.72 $\mu \mathrm{mol} \mathrm{g}^{-1} \mathrm{FW}$ ) and MDA (7.1-34 $\left.\mathrm{nmol} \mathrm{g}^{-1} \mathrm{FW}\right)$ gradually increased with dose of $\mathrm{NaCl}, \mathrm{P}<0.05$, Figure 3. Oxidant molecules did not show any significant differences up to $50 \mathrm{mmol} \mathrm{L}^{-1} \mathrm{NaCl}$ concentration for the accumulation of stress metabolites. The remarkable accumulation of stress metabolites was evident at 400 and 500 $\mathrm{mmol} \mathrm{L}{ }^{-1} \mathrm{NaCl}$ conditions. On the other hand, proline, an anti-stress metabolite, was accumulated right after $50 \mathrm{mmol} \mathrm{L}^{-1} \mathrm{NaCl}$ level indicating an adaptive characteristic of the halophyte. Similarly, Rubio et al. (2009) has observed greater oxidative damage in Lotus japonicus exposed to a high saline concentration, despite the maintenance of antioxidant levels.

Some authors consider that $\mathrm{H}_{2} \mathrm{O}_{2}$ accumulation under high saline concentrations may be a signal for an adaptative response to stress (Foyer et al., 1997). It has been demonstrated that $\mathrm{H}_{2} \mathrm{O}_{2}$ accumulation was involved in stomata closure induced by abscisic acid ( $A B A$ ) signalling (Zhang et al., 2001).

Antioxidant enzyme POX slightly increased up to $300 \mathrm{mmol} \mathrm{L}^{-1} \mathrm{NaCl}$ level, then slightly decreased (Figure 4A). Protease activity, on the other hand, gradually decreased upon increase of $\mathrm{NaCl}$ concentrations (Figure 4B) indicating depletion of proteins under stress conditions. Decrease in protein concentrations has been 
regarded as a defense response (Gupta and Huang, 2014). Since antioxidant or phenolic enzymes require proteins to synthesize enzymes and biochemical compounds etc. therefore, a gradual decrease in protease activity was evident. Similar reports were also made by SimovaStoilova et al. (2006) who showed a gradual decrease of protease in wheat plants under drought stress conditions.

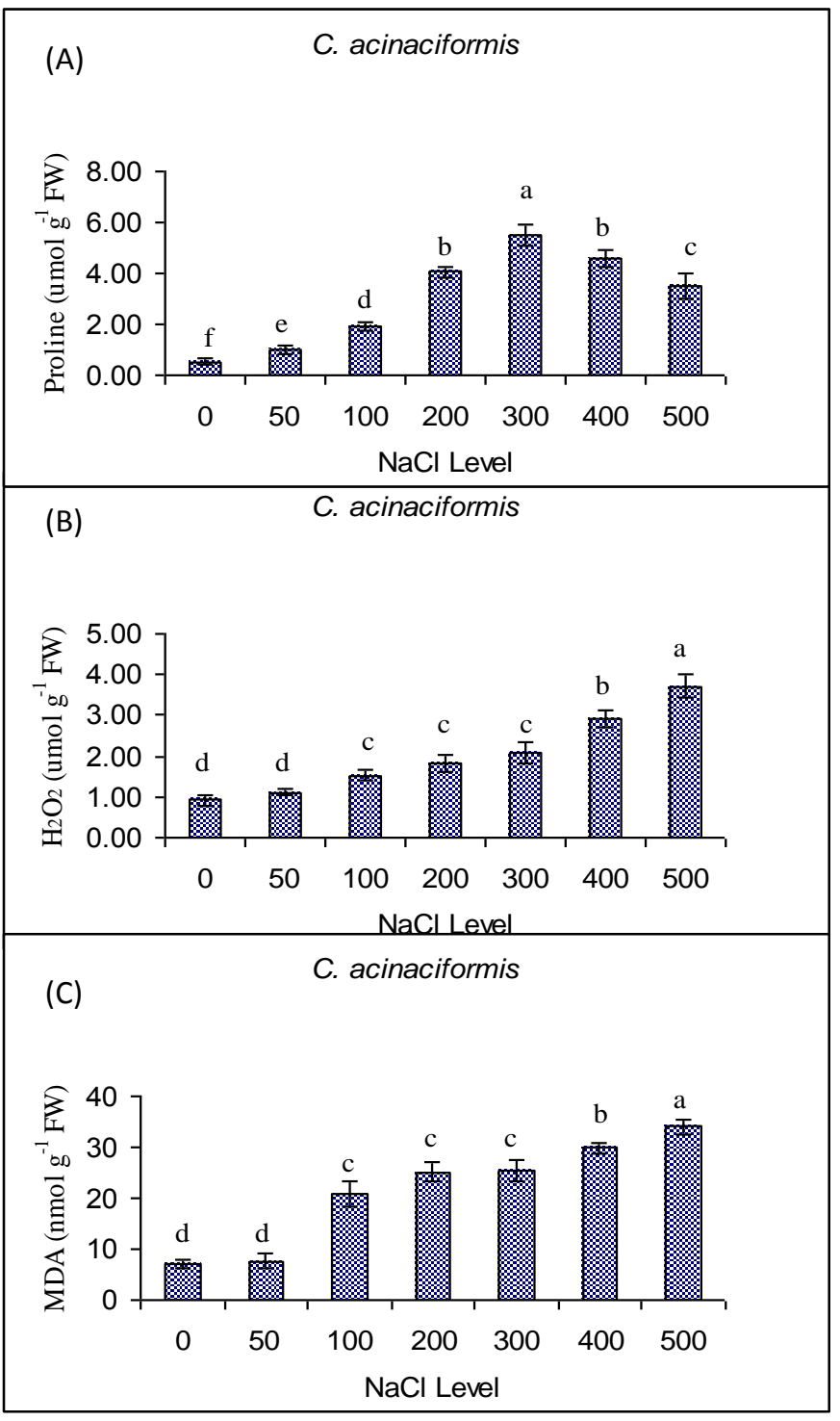

Figure 3. (A) Proline, (B) $\mathrm{H}_{2} \mathrm{O}_{2}$ and (C) MDA contents of $C$. acinaciformis under $\mathrm{NaCl}$ stress. Mean $\pm \mathrm{SE}$ of three replication. Different letters indicate significant differences $(\mathrm{P}<0.05)$.

Şekil 3. $\mathrm{NaCl}$ stresi altında C. acinaciformis bitkisinin (A) Prolin, (B) $\mathrm{H}_{2} \mathrm{O}_{2}$ ve (C) MDA içerikleri. Sonuçlar Ortalama $\pm \mathrm{SH}$ olarak ifade edilmiştir. Farklı harfler istatistik olarak önemli farklılıkları ifade etmektedir $(P<0.05)$.

CAT activity was not affected upon increase of $\mathrm{NaCl}$ concentrations (Figure 4C). Since CAT enzyme has a very short half-life, differences in enzyme expressions were not observed after 2week incubation in all $\mathrm{NaCl}$ conditions. This also indicated that the halophyte species showed similar response in all $\mathrm{NaCl}$ concentrations. Also, proteins have been reported to be separated into subunits, amino acids, under stress conditions (He, 2005). This might have also reduced the concentrations of proteins. Similar reports were also made by Shetti and Kaliwall (2017).

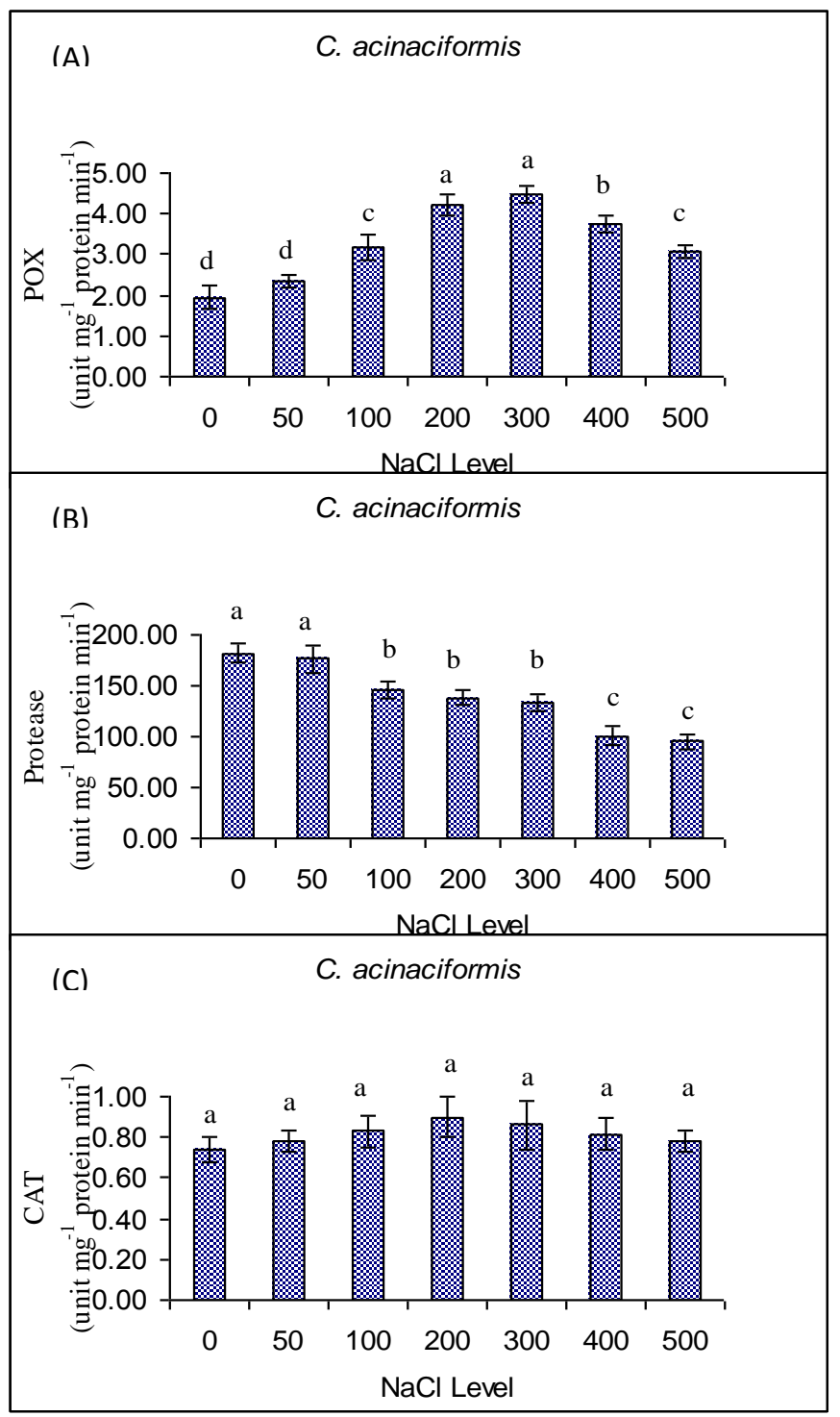

Figure 4. A) Peroxidase (POX), B) proteaz and C) catalase (CAT) of $C$. acinaciformis under $\mathrm{NaCl}$ stress. Mean \pm $\mathrm{SE}$ of three replication. Different letters indicate significant differences $(P<0.05)$.

Şekil 4. $\mathrm{NaCl}$ stresi altında C. acinaciformis bitkisinin (A) Peroksidaz (POX), (B) proteaz ve (C) katalaz (CAT) değerleri. Sonuçlar Ortalama $\pm \mathrm{SH}$ olarak ifade edilmiştir. Farklı harfler istatistik olarak önemli farklılıkları ifade etmektedir ( $p<0.05)$.

\section{Assessment of DNA damage caused by $\mathrm{NaCl}$}

C. acinaciformis did not show any dose response to $\mathrm{NaCl}$ stress up to $400 \mathrm{mmol} \mathrm{L}^{-1} \mathrm{NaCl}$ 
level with respect to DNA damages. DNA integrity measurement showed that DNA of the halophyte preserved its uniform shape and was not affected by the toxicity of $\mathrm{NaCl}$ as the other components of cell material (Figure 5). It is important to note that DNA of any organism is quite protected and surrounded by many layers. Therefore, it could be expressed that the only $400 \mathrm{mmol} \mathrm{L}^{-1}$ and above $\mathrm{NaCl}$ concentrations were able to cause DNA damages. It was observed that at high $\mathrm{NaCl}$ level, the halophyte was able to grow and produce FW and DW. Similarly, Karakas et al. (2017) tested four levels of saline soils which were cultivated with the halophyte species $S$. soda L. and $P$. oleracea L. in pots. The FW and DW of the halophytes were significantly greater in the moderately saline and highly saline soil types than in slightly saline and non-saline soil types. S. soda produced $43 \mathrm{~g}$ DW per pot while $P$. oleracea produced $40 \mathrm{~g}$ DW per pot in the highly saline soil type after 100 days of cultivation. The halophytes produced almost twice as much DW compared to non-saline soil treatment.

It was reported that DNA damages of potato plants were evident at $200 \mathrm{mmol} \mathrm{L}^{-1}$ concentrations. However, defense enzymes and metabolites responded at much lower concentrations indicating that DNA was the most resistant part of the cell components (Dikilitas et al., 2015). Therefore, DNA damages occurring under abiotic stress (such as salinity, drought, extreme temperatures) biotic stress (such as bacteria, viruses, fungi, parasites, weeds and insects) at their combination show the level of stress threshold that cause breaks in DNA. Stress that causes breaks in DNA structure is able to cause biochemical and physiological changes. A stress level that does not cause any breaks in DNA structure could be tolerated and biochemical or physiological changes could be normalized upon removal of stress factor. In this study, measurement of DNA damages via comet assay enabled us to determine what level of $\mathrm{NaCl}$ could be tolerated by $C$. acinaciformis halophyte species that is planned to use for phytoremediation purposes (Figure 6.).

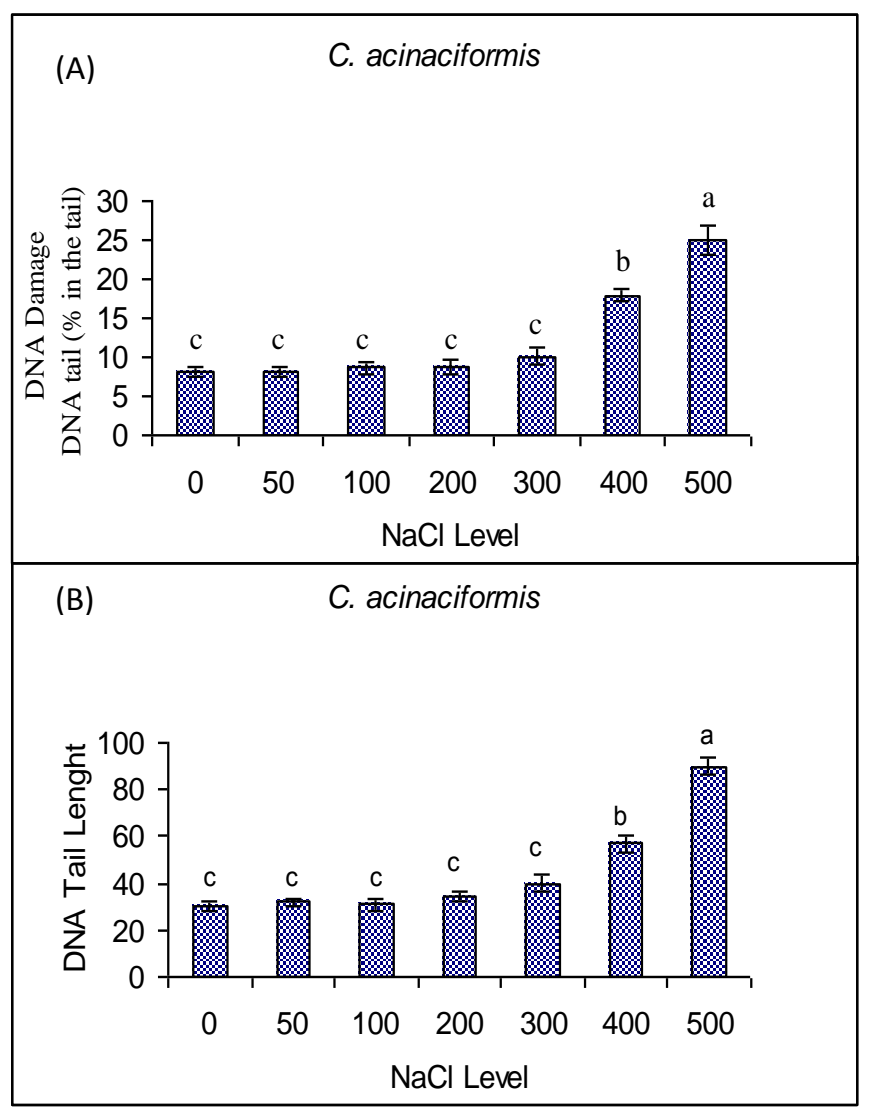

Figure 5. A) Percentage DNA damage and B) DNA tail length of $C$. acinaciformis under $\mathrm{NaCl}$ stress. Mean $\pm \mathrm{SE}$ of three replication. Different letters indicate significant differences $(\mathrm{P}<0.05)$.

Şekil 5. NaCl stresi altında C. acinaciformis bitkisinin (A) üzde DNA hasar ve (B) DNA kuyruk uzunluğu. Sonuçlar Ortalama \pm SH olarak ifade edilmiştir. Farklı harfler istatistik olarak önemli farklılıkları ifade etmektedir $(P<0.05)$.

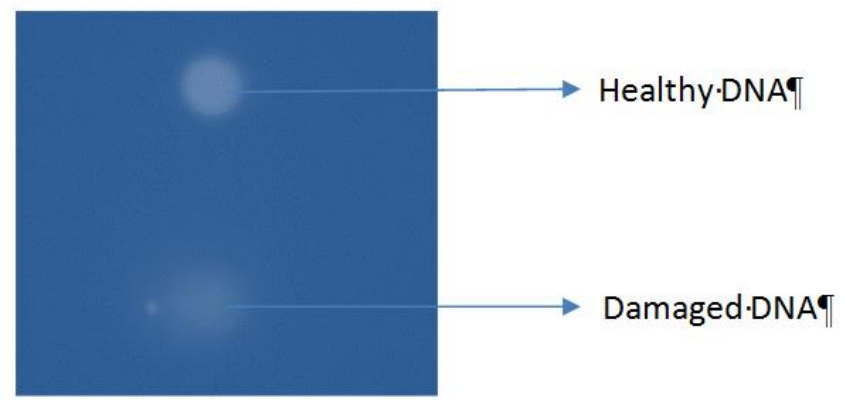

Figure 6. DNA damages of $C$. acinaciformis halophyte under $\mathrm{NaCl}$ stress.

Şekil 6. $\mathrm{NaCl}$ stresi altında C. acinaciformis bitkisinin DNA hasarları.

\section{Conclusions}

Halophyte plant C. acinaciformis grew rapidly at moderate salt concentrations and was able to survive at extreme saline conditions almost close to seawater salt concentrations. The present study showed that salinity triggered some solutes (proline, MDA and antioxidant enzymes). The 
plant could be easily used to remove salt up to $400 \mathrm{mmol} \mathrm{L}^{-1} \mathrm{NaCl}$ concentrations from the saline soil. Measuring DNA damage could be very useful to find out up to what level of $\mathrm{NaCl}$ could be tolerated if the halophyte is aimed to remediate the saline soils. This study is the first of its kind to measure the response of a halophyte in a molecular level measuring its DNA uniformly through assessing DNA damage or breaks. Our next study is underway which aims to find out the correlation among stress parameters and DNA health. We plan to determine what sorts of or what levels of stress metabolites would be able to affect DNA health and integrity.

\section{Acknowledgements}

The abstract of this study was presented in International Comet Assay Workshop (ICAW) taking place in Pamplona (Spain) from 29/08 till 31/08/2017.

\section{References}

Agarwal, S., Pandey, V. (2004). Antioxidant enzyme responses to $\mathrm{NaCl}$ stress in Cassia angustifolia. Biologia Plantarum, 48, 555-560.

Anjum, N.A., Gill, S.S., Ahmad, I., Tuteja, N., Soni, P., Pareek, A. (2012). Understanding stress-responsive mechanisms in plants: an overview of transcriptomics and proteomics approaches, in Improving Crop Resistance to Abiotic Stress, Vols. 1, 2, (Eds) Tuteja, N., Gill, S. S., Tiburcio, A.F., Tuteja R., (Weinheim: Wiley-VCH Verlag GmbH and Co. KGaA; ), 337-355 pp.

Arnon, D.L. (1949). A copper enzyme is isolated chloroplast polyphenol oxidase in Beta vulgaris. Plant Physiol., 24, 1-15.

Bates, L.S., Waldren R.P., Teare, I.D., 1973. Rapid determination of free proline for water-stress studies. Plant \& Soil, 39, 205-207.

Chérifi,K., Haddioui, A., El Hansali, M., Boufous, E.H. (2016). Growth and proline content in $\mathrm{NaCl}$ stressed plants of annual medic species. International Journal of Advanced Research in Biological Sciences, 3(9), 82-90.

Collins, A.R. (2004) The comet assay for DNA damage and repair. Molecular Biotechnology, 26: 249.

Cvikrova, M., Hrubcova, M., Vagner, M., Machackova, I., Eder, J. (1994). Phenolic acids and peroxidase activity in Alfalfa (Medicago sativa) embryogenic cultures after ethephon treatment. Plant Physiological, 91(2), 226-233.

D’Antonio, C.M. (1993). Mechanisms controlling invasion of coastal plant communities by the aalien succulent
Carpobrotus edulis. Ecology, 74, 83-95.

Dikilitaş, M., Collins, A.R., Koçyiğit A., EL Yamani, N., Karakaş S. (2015). DNA damage in potato plants exposed tohigh level of $\mathrm{NaCl}$ stress. ICAW 2015 - 11th International Comet Assay Workshop. 1-4 september 2015.

Flowers, T.J., Colmer, T.D. (2008). Salinity tolerance in halophytes. New Phytologist, 179, 945-963.

Flowers, T.J., Colmer, T.D. (2015). Plant salt tolerance: adaptations in halophytes. Ann. Bot. 115(3), 327331.

Foyer, C.H., Lopez-Delgado, H., Da,t J.F., Scott, .IM. (1997). Hydrogen peroxide and gluthatione-associated mechanisms of acclimatory stress tolerance and signalling. Physiologia Plantarum, 100, 241-254.

Gichner, T., Žnidar, I., and Száková, J. (2008). Evaluation of DNA damage and mutagenicity induced by lead in tobacco plants. Mutation Research, 652: 186-190.

Girard, C., Michaud, D., 2002. Direct monitoring of extracellular protease activities in microbial cultures. Analytical Biochemistry, 308: 388-391.

Grigore, MN, Ivanescu, L., Toma, C. (2014). Halophytes. An integrative anatomical study. Springer, Cham, Heidelberg, New York, Dordrecht, London, 1-2 pp.

Gupta, B., Huang, B. (2014). Mechanism of salinity tolerance in plants: physiological, biochemical, and molecular characterization. International Journal of Genomics, Article ID 701596, 18 pages.

He, Y. (2005). Changes in protein content, protease activity, and amino acid content associated with heath injury in creeping bentgrass. Journal of the American Society for Horticultural Science, 130(6): 842-847.

Heidari, A., Toorchi, M. Bandehagh, A., Shakiba, M.R. (2011). Effect of $\mathrm{NaCl}$ stress on growth, water relations, organic and inorganic osmolytes accumulation in sunflower (Helianthus annuus L.) lines. Universal Journal of Environmental Research and Technology 1(3), 351-362.

Joshi, M., Mishra, A., Jha, B. (2011). Efficient genetic transformation of Jatropha curcas L. by microprojectile bombardment using embryo axes. Industrial Crops and Products, 33, 67-77.

Karakas, S., Cullu, M.A., Dikilitas, M. (2017). Comparison of two halophyte species (Salsola soda and Portulaca oleracea) for salt removal potential under different soil salinity conditions. Turkish Journal of Agriculture and Forestry, 41, 183-190.

Kassaye, Y.A., Salbu, B., Skipperud, L., Einset., John. (2013). High tolerance of aluminum in the grass species Cynodon aethiopicus. Acta Physiologiae Plantarum, 35, 1749-1761.

Kurban, H., Saneoka, H., Nehira, K., Adilla, R., Premachandra, G.S., Fujita, K. (1999). Effect of salinity on growth, photosynthesis and mineral composition in leguminous plant Alhagi pseudoalhagi (Bieb.). Soil Science and Plant Nutrition, 45, 851-862.

Lei, Y., Xu, Y., Hettenhausen C., Lu, C., Shen, G., Zhang, Cuiping., Li, J., Song, J., Lin, H., Wu, J. (2018). Comparative analysis of alfalfa (Medicago sativa L.) leaf transcriptomes reveals genotype-specific salt tolerance mechanisms. BMC Plant Biology, 18:35.

Miller G, Suzuki N, Ciftci-Yilmaz S, Mittler R., Reactive oxygen species homeostasis and signalling during 
drought and salinity stresses. Plant,Cell and Environment, 33, 453-467.

Milosevic, N., Slusarenko, A.J. (1996). Active Oxygen Metabolism and Lignifications in The Hypersensitive Response in Bean. Physiological and Molecular Plant Pathology, 49: 143-158.

Parida, A.K., Das, A.B., Mittra, B., (2004). Effects of salt on growth, ion accumulation photosynthesis and leaf anatomy of the mangrove, Bruguiera parviflora. Trees: Structure and Function, 18, 167-174.

Pirasteh Anosheh, H., Ranjbar, G., Pakniyat, H., Emam, Y., (2016). Physiological mechanis of salt stress tolerance in plants; an overview. Editors: Azooz, M.M., Ahmad. P., Plant-environment interaction: responses and approaches to mitigate stress. Chichester: John Wiley \& Sons; 141-160pp.

Pourrut, B., Pinelli, E., Celiz, Mendiola, V., Silvestre ,J., Douay, F. (2015). Recommendations for increasing alkaline comet assay reliability in plants. Mutagenesis 30, 37-43.

Price, E.A.C., Marshall, C. (1999). Clonal plants and environmental heterogeneity. Plant Ecology, 141, 37.

Rubio, M.C, Bustos-Sammamed, P., Clemente, M.R., Becana, M. (2009). Effects of salt stress on expression of antioxidant genes and proteins in the model legume Lotus japonicus. New Phytologist, 181: 851-859.

Sairam, R.K., Sexena, D., (2000). Oxidative stress and antioxidants in wheat genotypes: possible mechanism of water stress tolerance. Journal of Agronomy and Crop Science, 184: 55-61.

Sairam, R.K., Srivastava, G.C., Agarwal, S., Meena, R.C. (2005). Differences in antioxidant activity in response to salinity stress in tolerant and susceptible wheat genotypes. Biologia Plantarum, 49 (1): 85-91.

Sharma, P, Jha, A.B, Dubey, R.S., Pessarakli, M., (2012). Reactive oxygen species, oxidative damage, and antioxidative defense mechanism in plants under stressful conditions. Hindawi Publishing Corporation Journal of Botany, Volume 2012, Article ID 217037.

Shetti, A.A., Kaliwal, B.B. (2017). Impact of imidacloprid intoxication on amylase and protease activity in soil isolate escherichia coli. Journal of Chemical and Pharmaceutical Research, 9(7):13-17.

Simova-Stoilova, L., Vassileva, V., Petrova, T., Tsenov, N., Demirevska, K., Feller, U., (2006). Proteolytic activity in wheat leaves during drought stress and recovery. General and Applied Plant Physioogy, Special Issue, 91-100.

Suehs, C.M., Médail, F., Affre L (2003) Invasion by South African Carpobrotus (Aizoaceae) taxa in the Mediterranean Basin: the effects of insularity on plant reproductive systems. In: Child $\mathrm{L}$ et al. (eds). Plant invasions: ecological threats and management solutions. Backhuys Publishers, 247-263pp.

Suo, J., Zhao, Q., David, L., Chen, S., Dai, S. (2017). Salinity Response in Chloroplasts: Insights from Gene Characterization. International Journal of Molecular Sciences, 18: 1011.

Traveset, A., Brundu, G., Carta, L., Mprezetou, I., Lambdon, P., et al. (2008). Consistent performance of invasive plant species within and among islands of the Mediterranean basin. Biological Invasions, 10(6): 847-858.

Tripathy, B.C., Oelmüller, R. (2012). Reactive oxygen species generation and signaling in plants. Plant Signaling Behavior, 7: 12, 1621-1633.

Velikova, V., Yordanov, I., Edreva, A., (2000). Oxidative stress and some antioxidant systems in acid rain treated Bean plants: Protective Role of Exogenous Polyamines. Plant Science, 151, 59-66.

Zadehbagheri, M., Azarpanah, A., Javanmardi, S. (2014). Proline metabolite transport an efficient approach in corn yield improvement as response to drought conditions. Nature, 566, 596. 